\title{
THE CALORIGENIC EFFECTS OF SOME THYROXINE ANALOGS ON INTACT ANIMALS AND ON EXCISED TISSUES *
}

\author{
By C. S. PITTMAN † AND S. B. BARKER
}

(From the Departments of Medicine and Pharmacology, the University of Alabama Medical
Center, and the Medical Service, Veterans Administration Hospital, Birmingham, Ala.)

(Submitted for publication September 25, 1961 ; accepted December 1, 1961)

Recently thyroxine analogs have enjoyed great attention among workers interested in the modus operandi of the thyroid hormones on a molecular level. It is apparent that some of these compounds, while calorigenically inactive themselves, may serve as specific antagonists of thyroid hormones (1). Others are effective as therapeutic agents in bringing about changes in lipid metabolism in patients with idiopathic hypercholesterolemia and atherosclerotic heart disease $(2,3)$. At the moment, there are no less than five analogs of widely different structures advocated by various investigators as being the most effective agents to lower serum cholesterol: D-thyroxine $(3,4)$; $3,5,3^{\prime}, 5^{\prime}$-tetraiodothyroformic acid $(4,5) ; 3,5,3^{\prime}$ triiodothyropropionic acid (6); 3,5,3'-triiodothyroacetic acid (2); and 3,5-diiodothyroacetic acid (7). As these and other analogs are rapidly gaining considerable clinical usage, the metabolic study of these compounds has lagged behind. We still have much to learn of 1) the fate of some of these compounds in the animal body, 2) the factors other than side chain differences which may be responsible for a lower calorigenic activity than the parent compounds, and 3) their effects on metabolism of the individual tissues. This report summarizes our results concerning the calorigenic effect of some thyroxine analogs on the diaphragm, heart, kidney, and liver as compared to that on the animal basal metabolic rate.

\section{METHODS}

General. Sprague-Dawley rats weighing 150 to $250 \mathrm{~g}$ were fed on laboratory chow and housed in a constant

* This study was supported in part by Research Grants A-1545 and A-4261 from the National Institutes of Health. An abstract of this paper has been sent to the Southern Section meetings of the American Federation for Clinical Research, January 18, 1962.

+ Clinical Investigator of Veterans Administration Hospital, Birmingham, Ala. temperature room at $25^{\circ} \mathrm{C}$. All the animals were approximately 6 weeks post surgical thyroidectomy at the start of each experiment. Every animal was checked for completeness of thyroidectomy during autopsy.

Thyroxine and all of the analogs ${ }^{1}$ were first dissolved in $0.1 \mathrm{~N} \mathrm{NaOH}$, then diluted with saline to the desired concentration of analog. The final concentration of $\mathrm{NaOH}$ was $0.02 \mathrm{~N}$, and 0.9 per cent $\mathrm{NaCl}$ solution, also containing $0.02 \mathrm{~N} \mathrm{NaOH}$, was employed as a control injection. All solutions were administered by the subcutaneous route. Each compound was tested at several dosage levels. At least one dosage produced metabolic changes equivalent to $1.28 \mu$ moles of $\mathrm{L}$-thyroxine so that results from animals of comparable metabolic state could be compared. No more than $25 \mu$ moles of any compound was given per $\mathrm{kg}$ body weight per day. When possible the data were analyzed according to the Student $t$ test (8).

Basal metabolic rate $(B M R)$. The apparatus used was similar to that described by Watts and Gourley (9), set up so that the oxygen consumption of 4 rats could be measured simultaneously. After a period of equilibration, at least three separate measurements were made during each run and the BMR was calculated as milliliters of oxygen consumed per $100 \mathrm{~g}$ body weight per hour.

Approximately 2 weeks before the start of an experiment the rats were put on a 5-hour feeding program (10) enabling their repeated use in a post-absorptive state. They were then placed in the BMR apparatus for training runs every day until reproducible measurements were obtained. The average BMR for 3 consecutive days was used as control. The animals were then given daily injections of a test solution for 4 days. The average BMR of the third, fourth, and fifth days after the start of injection was employed to represent the calorigenic effect of the analog and expressed as per cent increase of the control BMR.

Tissue oxygen consumption. The animals were given injections daily for 4 days of a test solution, as above. They were sacrificed on the fifth day by exsanguination under ether anesthesia, and the desired tissues were rapidly excised and chilled. The kidney, liver, and left ventricle of the heart were sliced by the Deutsch method

1 Thyroxine and its analogs studied in these experiments were kindly provided by Travenol Division of Baxter Laboratories; Smith, Kline and French Laboratories; and Warner-Lambert Research Institute. 
(11). The intact diaphragm was trimmed of its fat and the central tendon removed before careful division into quarters along the length of the muscle fibers; the thick portions were rejected. The tissue slices were then weighed on a Roller-Smith balance and placed in iced Warburg flasks. Each flask contained $3.0 \mathrm{ml}$ of incubation medium made up of Krebs-Ringer solution with $100 \mathrm{mg}$ glucose per $100 \mathrm{ml}$ and $0.01 \mathrm{M}$ phosphate buffer, $\mathrm{pH}$ 7.4. The oxygen consumption $\left(\mathrm{Qo}_{2}\right)$ of the tissues was measured according to the classical Warburg technique and was calculated as microliters of oxygen consumed per milligram of wet tissue weight per hour. The oxygen consumption of tissues from animals treated with the alkaline saline solution was used as control. The calorigenic effect of all test compounds was also expressed as per cent increase of control $\mathrm{Qo}_{\mathrm{z}}$.

\section{RESULTS}

Barker and Klitgaard found in 1952 (12) that, when a host animal was pretreated with large doses of thyroid hormones, the excised brain, lymphatics, and gonads did not show any calorigenic response. Therefore, the present study was limited to the excised diaphragm, heart, kidney, and liver. Our average control BMR for the thyroidectomized animals was $103.6 \mathrm{ml}$ oxygen per $100 \mathrm{~g}$ per hour. The control $\mathrm{Qo}_{2}$ for excised tissues was $0.86,1.84,3.54$, and $1.28 \mu l$ oxygen per $\mathrm{mg}$ per hour for diaphragm, heart, kidney, and liver, respectively.

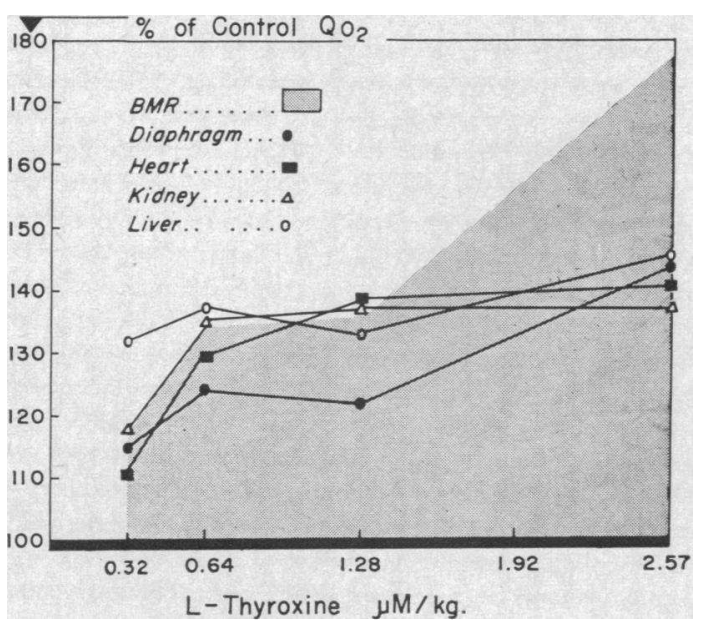

Fig. 1. Calorigenic effects of l-thyroxine. Thyroidectomized rats were given four daily injections of different doses of L-thyroxine. For each dosage level the result on the oxygen consumption of the whole animal represents one group of four animals, and that of excised tissues, one animal.

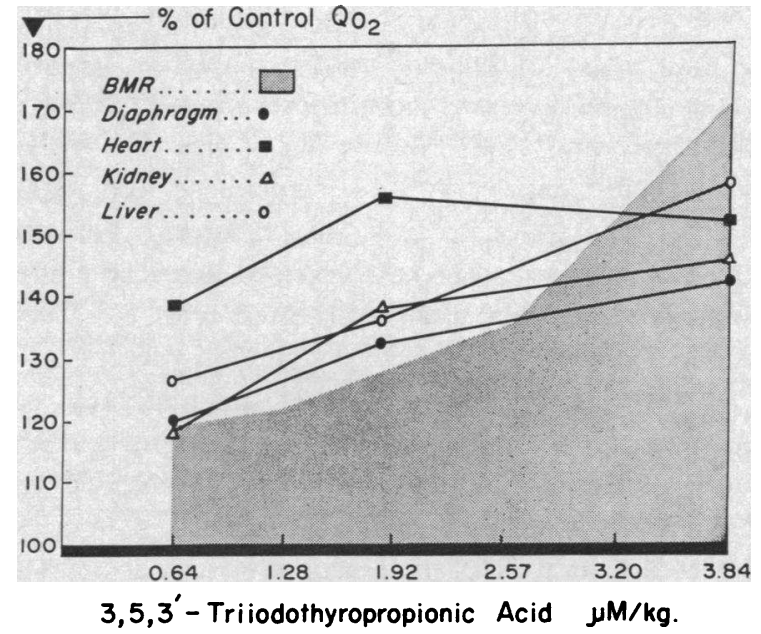

Fig. 2. Calorigenic efFect of $3,5,3^{\prime}$-tritodothyroPRoPIONIC ACID. Thyroidectomized rats were given four daily injections of different doses of the analog. For each dosage level, the result on the oxygen consumption of the whole animal represents one group of four animals, and that of excised tissues, one animal.

A comparison of the calorigenic effects of L-thyroxine on the whole animal and on individual tissues is shown in Figure 1. When L-thyroxine was given in dosage greater than $1.5 \mu$ moles per $\mathrm{kg}$ per day, the activity of the agitated animals contributed to the sharp increase of oxygen demand, and the metabolic rate obtained, no longer basal, rose much faster than the $\mathrm{Qo}_{2}$ of excised tissues with further increases of thyroxine. In the lower dosage range, the increase of oxygen consumption of the intact animal and that of the excised tissues were close if both were expressed as per cent of control.

A similar comparison of the calorigenic action of 3,5,3'-triiodothyropropionic acid is shown in Figure 2. As compared to L-thyroxine, 3,5,3'-triiodothyropropionic acid showed a much weaker calorigenic action, approximately half that of L-thyroxine. The response of the intact animal and of diaphragm, liver, and kidney correlated very well up to the highest testing dose, 3.84 $\mu$ moles per $\mathrm{kg}$ per day.

Barker (13) had previously observed that the calorigenic action of thyroid hormones on heart was more intense. He was able to demonstrate a definite response in heart slices 12 hours after the administration of thyroid hormones or their acetic acid analogs. Guz, Kurland and Freedberg (14) 
found that in myxedematous rabbits the increase of pulse rate could be shown as early as 3 hours after an intravenous administration of 3,5,3'-triiodothyronine, long before any rise of BMR. However, Saunders, Nuss, Greenberg and Holtkamp (15) failed to find any difference between the calorigenic response of excised heart and liver when the animals were pretreated with $3,5,3^{\prime}$-triiodothyroacetic acid or 3,5,3'-triiodothyronine.

Table I shows the ratios of the metabolic responses of heart to those of diaphragm, kidney, and liver. The compounds studied included the $\mathrm{L}$ - and D-isomers of thyroxine and 3,5,3'-triiodothyronine as well as their propionic and acetic acid analogs, several of which have been used on patients with atherosclerotic heart disease.

In Table I, only ranges of ratios are shown; no statistical analysis was attempted on the small samplings. Except in three instances, the ratio was consistently greater than unity for all compounds. 3,5,3'-Triiodo-D-thyronine and 3,5,3'triiodothyroacetic acid gave the highest ratios. The preparation of good heart slices was difficult. Heart $\mathrm{Qo}_{2}$ decreased rapidly if the tissue was allowed to stand after slicing or if the tissue was "leeched" by excessive Krebs-Ringer solution. Difference in such technical details may explain the finding of Saunders and co-workers (15).
In their study on the distribution of radioactive L- and D-isomers of thyroxine, Tapley, Davidoff, Hatfield and Ross (16) observed that L-thyroxine was preferentially taken up by the heart and striated muscle while D-thyroxine was more highly concentrated in the liver and kidney. The data of Dunne and Tapley (17) showed a lower calorigenic response by the striated muscle to D-thyroxine as compared to the L-isomer, and led to the conclusion that the low calorigenic activity of D-thyroxine in vivo was due to its lack of effect on the striated muscle.

Our results on D-thyroxine showed that this compound has a very low calorigenic activity. In order to elevate metabolism 30 per cent over control, it required $6.40 \mu$ moles per $\mathrm{kg}$ per day of D-thyroxine for 4 days but only $1.28 \mu$ moles per $\mathrm{kg}$ per day of L-thyroxine, giving a potency ratio of $1: 5$. But contrary to the observation of Dunne and Tapley (17), diaphragm as a striated muscle did not show a uniquely low response to D-thyroxine. In dosages mentioned above, D-thyroxine increased the oxygen consumption 19.3 per cent above control and L-thyroxine 21.6 per cent. In their study, Dunne and Tapley compared the tissues from rats pretreated with $6 \mathrm{mg}$ (or 7.68 $\mu$ moles) per $\mathrm{kg}$ per day of L-or D-thyroxine. In our experience, rats receiving this amount of

TABLE I

A comparison of tissue responses to thyroxine analogs *

\begin{tabular}{|c|c|c|c|c|c|}
\hline Compound & Dose & $\begin{array}{l}\text { No. of } \\
\text { animals }\end{array}$ & Heart/diaphragm & Heart/kidney & Heart/liver \\
\hline L-Thyroxine & $\begin{array}{c}\text { Mmoles } / \mathrm{kg} \\
2.57 \\
1.28\end{array}$ & $\begin{array}{l}5 \\
4\end{array}$ & $\begin{array}{l}1.0-3.4 \\
1.7-6.0\end{array}$ & $\begin{array}{l}1.6-3.5 \\
1.4-3.6\end{array}$ & $\begin{array}{l}0.9-3.9 \\
1.4-4.9\end{array}$ \\
\hline $3,5,3^{\prime}$-Triiodo-L-thyronine & $\begin{array}{l}2.57 \\
0.68\end{array}$ & $\begin{array}{l}1 \\
1\end{array}$ & $\begin{array}{l}2.1 \\
1.1\end{array}$ & $\begin{array}{l}1.8 \\
1.4\end{array}$ & $\begin{array}{l}1.6 \\
0.9\end{array}$ \\
\hline D-Thyroxine & 6.40 & 3 & $1.8-7.4$ & $1.2-4.4$ & $0.9-2.6$ \\
\hline 3,5,3'-Triiodo-D-thyronine & 1.90 & 3 & $5.7-11.9$ & $3.3-6.6$ & $3.9-4.5$ \\
\hline $\begin{array}{l}3,5,3^{\prime}, 5^{\prime} \text {-Tetraiodothyro- } \\
\text { propionic acid }\end{array}$ & $\begin{array}{r}11.52 \\
7.68\end{array}$ & $\begin{array}{l}2 \\
3\end{array}$ & $\begin{array}{l}1.8-5.0 \\
1.1-7.8\end{array}$ & $\begin{array}{l}1.8-5.2 \\
3.6-6.1\end{array}$ & $\begin{array}{l}2.0-2.6 \\
1.3-1.7\end{array}$ \\
\hline $\begin{array}{l}3,5,3^{\prime} \text {-Triiodothyropropionic } \\
\text { acid }\end{array}$ & $\begin{array}{l}5.76 \\
2.57\end{array}$ & $\begin{array}{l}2 \\
1\end{array}$ & $\begin{array}{l}2.2-3.0 \\
1.4\end{array}$ & $\begin{array}{l}2.4-3.8 \\
1.5\end{array}$ & $\begin{array}{l}1.8-2.0 \\
1.1\end{array}$ \\
\hline $\begin{array}{l}3,5,3^{\prime}, 5^{\prime} \text {-Tetraiodothyro- } \\
\quad \text { acetic acid }\end{array}$ & 2.57 & 2 & $1.8-2.4$ & $2.1-2.6$ & $0.9-1.3$ \\
\hline $3,5,3^{\prime}$-Triiodothyroacetic acid & $\begin{array}{l}2.57 \\
0.77\end{array}$ & $\begin{array}{l}2 \\
1\end{array}$ & $\begin{array}{c}4.8-6.0 \\
1.1\end{array}$ & $\begin{array}{l}3.6-4.6 \\
1.4\end{array}$ & $\begin{array}{l}3.0-3.8 \\
1.2\end{array}$ \\
\hline
\end{tabular}

* Thyroidectomized rats were given four daily injections of thyroxine analogs to produce a metabolic state comparable to that effected by four injections of 1.28 or $2.57 \mu$ moles of $\mathrm{L}$-thyroxine per $\mathrm{kg}$ per day. The oxygen consumption of excised tissues was calculated as per cent over control. Then the ratios of response of heart to diaphragm, to kidney, and to liver were compared. 
TABLE II

Effects of thyroxine analogs with $3,3^{\prime}$ - and $3,3^{\prime}, 5^{\prime}$-iodination on $B M R$ and tissue metabolism of thyroidectomized rats *

\begin{tabular}{|c|c|c|c|c|c|c|}
\hline Compound & Dose & $\begin{array}{c}\text { Whole } \\
\text { animal } \\
\text { BMR }\end{array}$ & Diaphragm & Heart & Kidney & Liver \\
\hline & $\mu$ moles $/ \mathrm{kg}$ & \multicolumn{5}{|c|}{$\%$ increase over control QO2 } \\
\hline $3,3^{\prime}, 5^{\prime}$-'Triiodo-DL-thyronine & 25.7 & -0.4 & +8.2 & +14.5 & $(+6.5)$ & +5.7 \\
\hline $\begin{array}{l}3,3^{\prime}, 5^{\prime}-\text { Triiodothyropropionic } \\
\text { acid }\end{array}$ & 25.7 & -1.2 & +11.5 & 0.0 & -3.0 & -3.3 \\
\hline $\begin{array}{l}3,3^{\prime}, 5^{\prime}-\text { Triiodothyroacetic } \\
\text { acid }\end{array}$ & 25.7 & -6.2 & +13.7 & -20.0 & $(+17.0)$ & -4.8 \\
\hline 3,3'-Diiodo-DL-thyronine & 25.7 & +3.0 & +10.2 & +3.9 & +7.6 & -9.5 \\
\hline $\begin{array}{l}\text { 3,3'-Diiodothyropropionic } \\
\text { acid }\end{array}$ & 25.7 & -4.3 & +5.1 & +20.7 & +3.2 & -3.7 \\
\hline \multirow[t]{2}{*}{ 3,3'-Diiodothyroacetic acid } & 25.7 & -0.4 & +23.3 & -5.5 & +11.4 & -15.2 \\
\hline & & $m l O_{2} / 100 \mathrm{~g} / \mathrm{hr}$ & & $\mu l O_{2} / m g / h r$ & & $\mu l \mathrm{O}_{2} / \mathrm{mg} / \mathrm{hr}$ \\
\hline Control & 0.0 & 103.6 & 0.86 & 1.84 & 3.54 & 1.28 \\
\hline
\end{tabular}

* All the thyroxine analogs in this group were known to be effective as antagonists which block the calorigenic effects of L-thyroxine. The animals were given daily injections of the analogs for 4 days, at a uniform dosage of $25.7 \mu \mathrm{moles} / \mathrm{kg} /$ day. The oxygen consumption was calculated as per cent increase over control. The results on whole animal BMR represent the average of 1 to 3 groups of animals with 4 rats in each group. The results of tissue metabolism represent the average of 2 to 10 rats. The data enclosed in parentheses have probability values less than 0.05 and greater than 0.01 . The probability values of the rest of data are 0.1 to 0.8 .

L-thyroxine become extremely toxic, with prostration, diarrhea, and frequently 20 per cent weight loss. This difference in experimental condition may possibly explain the discrepancy in our findings.

We studied six additional thyroxine analogs with iodination at positions $3,3^{\prime}$ or $3,3^{\prime}, 5^{\prime}$, bearing only one iodine substitution on the inner ring. Not only do these compounds exhibit less than 3 per cent of thyroxine calorigenic activity (18), but they have been found to be effective antagonists of the calorigenic action of thyroxine in athyreotic rats (1) and in human subjects (19). The results in Table II show that at as high a dose as $25.7 \mu$ moles per $\mathrm{kg}$ per day for 4 days, the animals did not show any rise of BMR. The results on excised tissues were more varied, but, with two exceptions (enclosed in parentheses in Table II), none of the tissues showed a definite rise of oxygen consumption (probability greater than 0.05 ) in response to any of these six analogs.

\section{DISCUSSION}

It is generally assumed that the contribution of any individual organ to the whole animal BMR is a function of its characteristic rate of cellular metabolism and its mass. Precise correlation is diffi- cult, since the oxygen consumption of excised tissue is not necessarily representative of the oxygen consumption of tissue in vivo, even under a resting state. During the usual manometric procedure, neither the tone nor the integrity of heart or striated muscle is maintained. In fact, the oxygen consumption of these tissues measured in the first half hour is often significantly higher than that obtained in the second half hour, indicating deterioration with time. Nevertheless, our results show that the increased $\mathrm{Qo}_{2}$ of excised diaphragm, heart, kidney, and liver parallels the change of whole animal BMR, with the response of heart being somewhat more intense.

In a careful study of 150 thyrotoxic patients, Sandler and Wilson (20) showed that thyrotoxicosis may act as the determining factor precipitating serious disturbance of cardiac function and rhythm, particularly in the presence of associated heart disease. Many other investigators have observed that angina pectoris could be induced by thyroxine analogs as well as by the thyroid hormones themselves $(4,21)$. Boyd and Oliver (4) studied the effect of several $\mathrm{D}$-isomers and fatty acid analogs of thyroid hormones on the serum cholesterol of euthyroid men with ischemic heart disease and hypercholesterolemia. During their 
study angina appeared in 34 patients, 14 of whom showed no discernible elevation of BMR. Greene, Pearce and Rideout (22) also observed angina pectoris without measurable change of $B M R$ in a healthy physician serving as control during their study of 3,5,3'-triiodothyroacetic acid.

Our findings on the excised tissues offer a possible explanation for these clinical observations. The L- and D-isomers of both thyroid hormones, as well as their propionic and acetic acid analogs, consistently showed a larger stimulatory effect on heart tissue metabolism than on that of diaphragm, kidney, or liver. Assuming that in a "70 kilo man" the heart weighs $400 \mathrm{~g}$, or 0.6 per cent of the body weight, an appreciable elevation in the cardiac metabolism in vivo would not be reflected by measurements of the entire BMR. Thus, thyroxine and its analogs at low dosage may conceivably increase the oxygen demand of the heart without measurable effect on whole body BMR.

The interaction of thyroxine analogs and catecholamines may offer an alternate explanation, but has not been completely explored. In a preliminary report, Wiswell, Hurwitz, Coronho and Bing (23) suggested that in thyrotoxicosis the metabolism of catecholamines might be altered. The metabolism of catecholamines may also be altered in patients given thyroxine analogs, although such a study is not yet available. It is entirely possible that these compounds may produce relative myocardial ischemia and angina pectoris through potentiation of catecholamines, even in euthyroid patients.

The therapeutic value of lowering the levels of serum and liver cholesterol is currently still in dispute and it is outside the scope of this report to comment on the individual merit of the various thyroxine analogs as achieving such a state. Suffice it to say that avoidance of myocardial ischemia is paramount in the treatment and management of patients with atherosclerotic heart disease. The value of any therapy which may increase myocardial ischemia, relative or absolute, must be questioned. Our results show that heart tissue itself is very sensitive to the calorigenic effect of several of the thyroxine analogs which are currently popular as therapy for hypercholesterolemia and atherosclerotic heart disease. Therefore, while some thyroxine analogs have been demonstrated to lower the serum and liver cholesterol, the ideal therapeutic agent for atherosclerosis is yet to be found.

\section{SUMMARY}

The calorigenic effects of thyroxine and 13 of its analogs were studied in thyroidectomized animals as well as in excised diaphragm, heart, kidney, and liver. Within moderate dosage range, both experimental procedures gave comparable results. None of the analogs showed a truly unique effect on any of the four tissues, although the response of heart was consistently higher than that of the other tissues. Attention is called to reports that a considerable proportion of patients given thyroxine analogs for reduction of serum cholesterol may experience angina pectoris without measurable elevation of basal metabolism rate. Our findings on cardiac tissue metabolism may furnish the basis for this clinical observation.

\section{REFERENCES}

1. Pittman, C. S., and Barker, S. B. Antithyroxine effects of some thyroxine analogues. Amer. J. Physiol. 1959, 197, 1271.

2. Trotter, W. R. Effect of triiodothyroacetic acid on blood-cholesterol levels. Lancet 1956, 1, 885.

3. Symposium on Sodium D-thyroxine. Chicago, Baxter Laboratories, December 5, 1959.

4. Boyd, G. S., and Oliver, M. F. The effect of certain thyroxine analogues on the serum lipids in human subjects. J. Endocr. 1960, 21, 33.

5. Corday, E., Jaffe, H., and Irving, D. W. Hypercholesterolemic effect of tetraiodothyroformic acid on brittle coronary patients. Arch. intern. Med. 1960, 106, 809.

6. Leeper, R. D., Benua, R. S., Kumaoka, S., and Rawson, R. W. Metabolic effects of $3: 5: 3^{\prime}$-triiodothyropropionic acid in Derivatives and Isomers of the Thyroid Hormones, M. L. Sachs, Ed. Philadelphia, University of Pennsylvania, 1960, p. 61.

7. Ruegamer, W. R., Alpert, M. E., and Silverman, F. R. Thyroxine analogues and cholesterol metabolism: The relative effects of various thyroxine derivatives on growth, oxygen consumption and tissue cholesterol concentration in the rat. Endocrinology 1960, 66, 160.

8. Fisher, R. A. Statistical Methods for Research Workers. Edinburgh, Oliver and Boyd, 1950, p. 134.

9. Watts, D. T., and Gourley, D. R. H. A simple apparatus for determining basal metabolism of small animals in student laboratory. Proc. Soc. exp. Biol. (N. Y.) 1953, 84, 585.

10. Barker, S. B. A limited feeding regime for rats. Proc. Soc. exp. Biol. (N. Y.) 1949, 72, 198. 
11. Deutsch, W. An improvement of Warburg's method for cutting tissue slices for respiratory experiments. J. Physiol. (Lond.) 1936, 87, 56 P.

12. Barker, S. B., and Klitgaard, H. M. Metabolism of tissues excised from thyroxine-injected rats. Amer. J. Physiol. 1952, 170, 81.

13. Barker, S. B. Metabolic action of thyroxine derivatives and analogs. Endocrinology 1956, 59, 548.

14. Guz, A., Kurland, G. S., and Freedberg, A. S. Heart rate and $\mathrm{O}_{2}$ consumption after triiodothyronine in the myxedematous rabbit. Amer. J. Physiol. 1961, 200, 58.

15. Saunders, H. L., Nuss, D., Greenberg, C. M., and Holtkamp, D. E. Effect of pretreatment with 3:5: 3'-triiodothyroacetic acid or L-3: $5: 3^{\prime}$-triiodothyronine on the oxygen uptake of rat heart and liver slices. Fed. Proc. 1958, 17, 408.

16. Tapley, D. F., Davidoff, F. F., Hatfield, W. B., and Ross, J. E. Physiological disposition of D- and L-thyroxine in the rat. Amer. J. Physiol. 1959, 197, 1021.

17. Dunne, P. B., and Tapley, D. F. Oxygen consump- tion by tissues from rats injected with L- or D-thyroxine. Nature (Lond.) 1960, 185, 622.

18. Stasilli, N. R., Kroc, R. L., and Meltzer, R. I. Antigoitrogenic and calorigenic activities of thyroxine analogues in rats. Endocrinology 1959, 64, 62.

19. Pittman, J. A., Tingley, J. O., Nickerson, J. F., and Hill, S. R., Jr. Antimetabolic activity of $3: 3^{\prime}: 5^{\prime}$ triiodo-DL-thyronine in man. Metabolism 1960, 9, 293.

20. Sandler, G., and Wilson, G. M. The nature and prognosis of heart disease in thyrotoxicosis Quart. J. Med. 1959, 28, 347.

21. Ibbertson, K., Fraser, R., and Alldis, D. Rapidly acting thyroid hormones and their cardiac action. Brit. med. J. 1959, 2, 52.

22. Greene, R., Pearce, J. F., and Rideout, D. F. Effect of D-thyroxine on serum cholesterol. Brit. med. J. 1961, 1, 1572.

23. Wiswell, J. G., Hurwitz, G. E., Coronho, V., and Bing, O. H. L. Urinary catechol amines and VMA in patients with hyperthyroidism and hypothyroidism in Program of the Forty-third Meeting of the Endocrine Society, 1961, p. 32.

\section{ANNOUNCEMENT OF MEETINGS}

The Nineteenth Annual Meeting of THE AMERICAN FEDERATION FOR CLINICAL RESEARCH will be held in Atlantic City, N. J., on Sunday, April 29, 1962 at 9:00 a.m. at the Casino Theatre on the Steel Pier. On Sunday afternoon, April 29, 1962, joint sectional meetings with The American Society for Clinical Investigation will be held in rooms in Chalfonte-Haddon Hall; and on Sunday evening, additional meetings will be held under the auspices of The American Federation for Clinical Research, in Chalfonte-Haddon Hall.

The Fifty-fourth Annual Meeting of THE AMERICAN SOCIETY FOR CLINICAL INVESTIGATION, INC., will be held in Atlantic City, N. J., on Sunday afternoon, April 29, 1962, in Chalfonte-Haddon Hall in simultaneous programs sponsored in conjunction with The American Federation for Clinical Research; and on Monday, April 30, at 9:00 a.m. at the Casino Theatre on the Steel Pier.

THE ASSOCIATION OF AMERICAN PHYSICIANS will hold its Seventy-fifth Annual Meeting at Atlantic City, N. J., at the Casino Theatre on the Steel Pier on Tuesday, May 1, 1962, at 9:30 a.m., and in the Vernon Room, Chalfonte-Haddon Hall on Wednesday, May 2, 1962, at 9:30 a.m. 